\title{
Kimberlite-carbonatite relationships revisited: evidence from Khaderpet pipe, Andhra Pradesh, India
}

\author{
Biplob Chatterjee ${ }^{1}$, Stephen E. Haggerty ${ }^{2}$, A. D. Beard ${ }^{3}$, Chris B. Smith ${ }^{4}$, Roger Townend ${ }^{5}$ \\ ${ }^{1}$ Rio Tinto Exploration Ltd., Bangalore, India, \\ ${ }^{2}$ Florida International University, Miami, USA, \\ ${ }^{3}$ Birkbeck College, London, UK, \\ ${ }^{4}$ Rio Tinto Mining and Exploration Ltd., Bristol, UK, \\ ${ }^{5} R$. Townend \& Associates, Malaga, Western Australia
}

The 30 ha Khaderpet Pipe is a unique kimberlite carbonatite association (Fig. 1), one of 14 kimberlite pipes discovered by Rio Tinto Exploration (RTX) between 2001-2004 during its prospecting of the Wajrakarur Kimberlite Field (WKF).

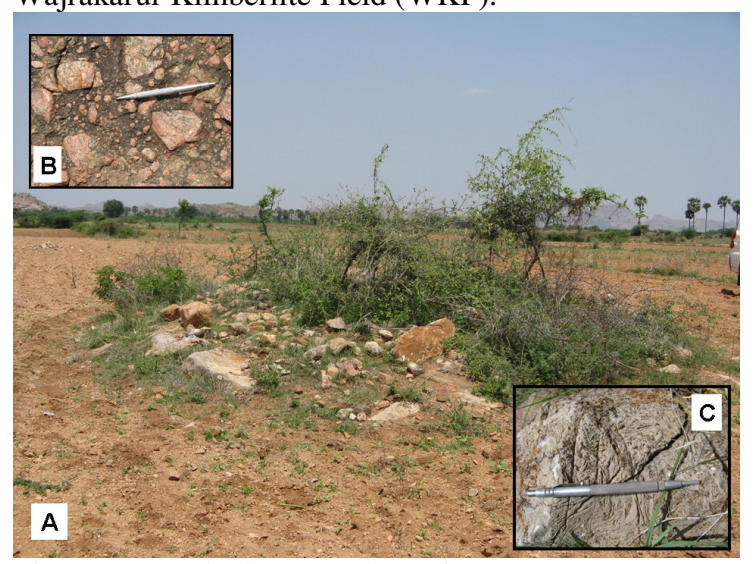

Fig. 1: A - Khaderpet carbonatite outcrop (Inset C close-up view of carbonatite). Kimberlite breccia (close-up view in inset B) surrounds the carbonatite

\section{Regional Geological Setting:}

More than 150 kimberlite and lamproite occurrences are now known from the Dharwar Craton (Fig. 2), an Archean cratonic nucleus containing narrow to broad arcuate Late Archean supracrustal greenstone belts of Dharwar Supergroup. The greenstones stratigraphically overly the composite migmatite gneiss known as Peninsular Gneissic Complex (PGC), which is an extensively remobilized basement (Naha et al., 2005), dated older than 3.3 Ga (Bhaskar Rao et al, 1991). The craton has been subdivided into an eastern and a western block, based on significantly different evolutionary history. The two blocks have cratonised along the sheared eastern margin of the Chitradurga Greenstone Belt during the emplacement of large granitic plutons of Closepet Granite dating approximately $2500 \mathrm{Ma}$ (Gupta et al., 2003). Multiple phases of Proterozoic dolerite intrusive swarms indicate the shallow level brittleness of the Dharwar crust. Mesoproterozoic and Neoproterozoic platform sediments (Cuddapah and the Kurnool Groups, respectively) were deposited in fault bounded basins in the eastern and northern margins of Dharwar Craton.
GSI study indicates that the modern heat flow gradient within the Dharwar Craton is $\sim 40 \mathrm{~mW} / \mathrm{m}^{2}$. Seismic tomography indicates that the region has a lithospheric thickness of $>200 \mathrm{~km}$.

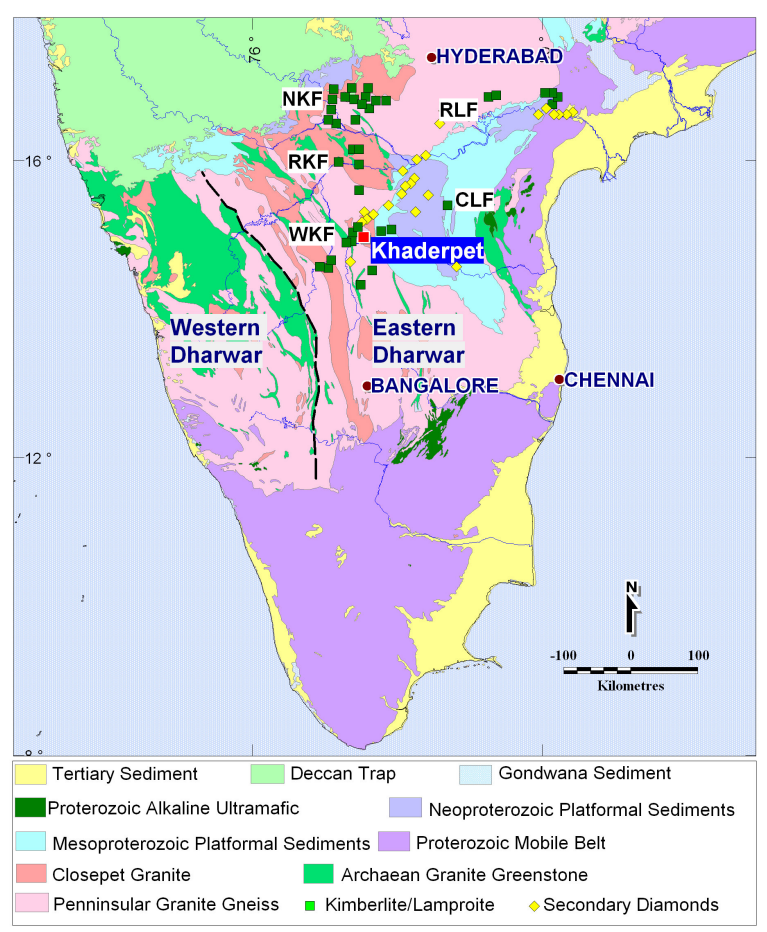

Fig. 2: Regional geological setting of Khaderpet pipe (Kimberlite Fields - NKF-Narayanpet, RKF-Raichur, WKF-Wajrakarur, Lamproite Fields - RLFRamanapeta, CLF- Chelima)

Kimberlites and lamproites of two distinct ages, viz. $1400 \mathrm{Ma}$ and $1100 \mathrm{Ma}$ (Kumar et al., 2001, Chalapathi Rao, 2007) intrude the eastern block of Dharwar Craton. Ramanapeta and Chelima Lamproite Fields occur along the contact of the eastern block with the Proterozoic Eastern Ghats Mobile Belt.

\section{Wajrakarur Kimberlite Field (WKF)}

WKF is the only proven diamondiferous kimberlite field in the Dharwar Craton. Over 40 diamond bearing kimberlites occur along a $120 \mathrm{~km}$ x $60 \mathrm{~km}$ linear NE trend. Individual clusters of kimberlites in WKF tend to 
occur on E trends. Kimberlites ( 1100 Ma, Kumar et al., 2001) have been emplaced within the Archean crystallines or the Mesoproterzoic (Cuddapah) sediments and range from $>85 \mathrm{Ha}$ (Anumpalle kimberlite) to $<1 \mathrm{Ha}$ Gooty kimberlite. The WKF intrusives have been described as Group 1 hypabyssal facies magmatic to pelletal tuffisitic (phlogopite or melilite or monticellite) kimberlite breccia (Scott Smith, 2007). High pressure xenocrysts in WKF kimberlites include subcalcic harzburgitic (G10), lherzolitic (G9), eclogitic (G3) and titanian (G1 and G2) pyrope, picro-chromites, picro-ilmenites, chrome diopsides and diamonds. Nickel geothermometry from pyrope recovered from WKF indicate geotherms from $38 \mathrm{~mW} / \mathrm{m}^{2}$ to $42 \mathrm{~mW} / \mathrm{m}^{2}$ corresponding to $1100 \mathrm{Ma}$ lithospheric thicknesses of 180 to $200 \mathrm{~km}$.

\section{Khaderpet Kimberlite - Carbonatite Association}

Khaderpet pipe is one of the six kimberlites occurring in the Anumpalle Cluster of WKF having an Etrending linear span of $5 \mathrm{~km}$. Khaderpet pipe $(\sim 20 \mathrm{Ha})$ was discovered during the follow up prospecting of coincident kimberlitic indicator mineral and aeromagnetic anomalies.

All the kimberlites in the Anumpalle cluster are hypabyssal facies kimberlite breccia and show complete alteration of olivine to serpentine, and intense secondary carbonate alteration. However, Khaderpet kimberlite has a discrete sovite intrusive phase within the kimberlite breccia (Fig. 3), not noticed anywhere else in the Wajrakarur kimberlite field.
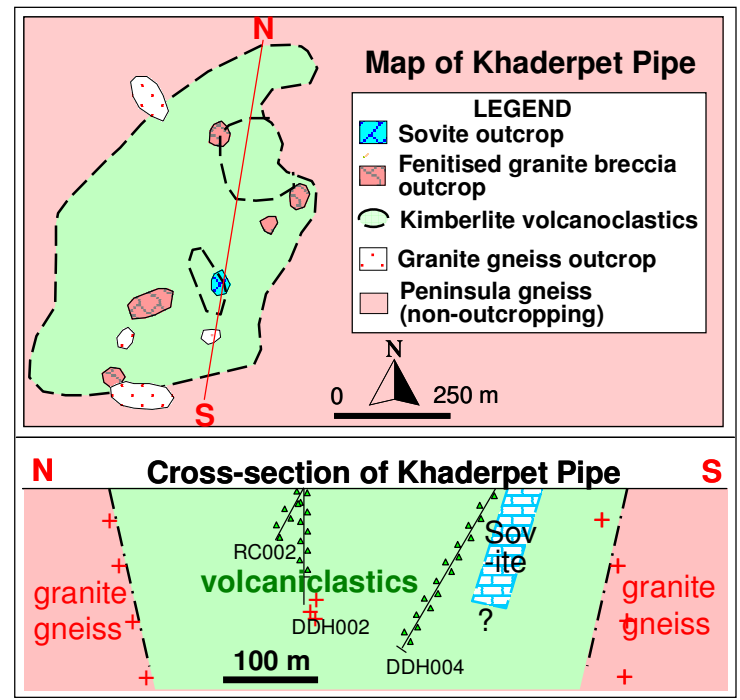

Fig. 3. Map and cross-section of Khaderpet Pipe

Khaderpet Pipe consists predominately of clastsupported lithic breccia and crystal lithic tuffs, where the clasts are green-stained, fenitised, former quartz monzonite from adjacent country rock and crystals derived from it.

Clasts show a weak sub-horizontal imbrication. Feldspars in the monzonite are often reddened by the fenitisation; the overall green colour is due to chlorite development around grain boundaries. There are minor amphibolite and pyroxenite clasts. The dilute matrix to the breccia is a diamondiferous olivine-rich ultramafic containing accessory pyrope (lherzolitic G9 dominant, but $25 \%$ eclogitic and $10 \%$ subcalcic G10, see Fig. 5), magnesiochromite, chrome diopside, and rare picroilmenite and Ti-poor andradite. This last named could suggest an affinity with ultramafic lamprophyres (terminology of Rock, 1991) such as olivine melilitite.
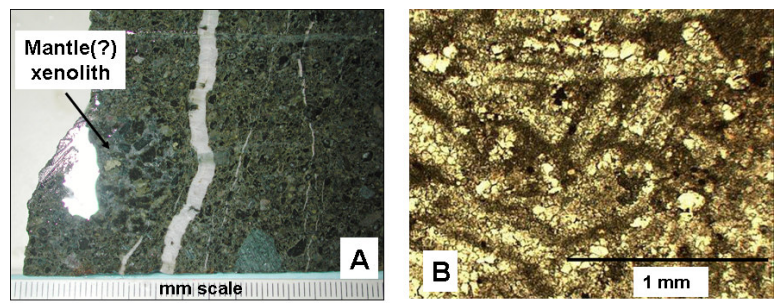

Fig. 4 - A. Kimberlite tuff with carbonate veins from drill core. Kimberlite clasts show sub-horizontal imbrication. B. - Photomicrograph of flow banded calcite crystals from sovite outcrop.

The rounded-elongate former olivines are now pseudomorphed by talc and clay mineral (Mg-rich saponite) (Fig. 4 A). In the eastern part of the body an intrusive plug of sovite carbonatite subcrops over an area of 45 x $60 \mathrm{~m}$ (Fig. 3). Thin veinlets of chevronstructured carbonate extend into the adjacent breccias. The carbonatite is composed of calcite that forms polycrystalline lath shapes to $0.5 \mathrm{~mm}$ (Fig. 4B). Locally these are sub-parallel, suggestive of flow, and are separated by a very minor matrix of yellow brown phyllosilicate. Oblate spheroids of polycrystalline calcite are sporadic and pelletal in appearance, and in fine grained silicate matrices these may be immiscible liquids; such spheroids are characteristic of carbonatites, and immiscibility is a feature of carbonate-rich kimberlites. Xenocrystic mineral phases recovered from the carbonatite are very similar to those recovered from the matrix of the kimberlite breccia and include diamonds.
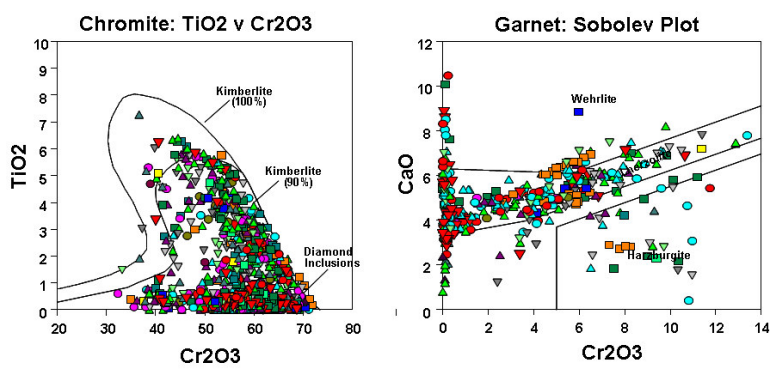

Fig. 5 - Discrimination plots of xenocrysts derived from Khaderpet kimberlite - carbonatite association. All the red plots are xenocrysts derived from sovite

The overall appearance of tuffs and breccias in the Anumpalle cluster of kimberlites including Khaderpet pipe suggests terminal blocked vent accumulations during conditions of underpressure, with spallation of country rock causing abundance of granitoid debris. Conditions fit the model proposed by Sparks (2006) for the terminal phase of kimberlite pipe development. 
Geochemically Pipe 3016 is heavily contaminated with Clement CI indices of $>4$ for the ultramafic with carbonate veins, rising higher through the breccia as the proportion of country rock increases. The trend of steadily increasing contamination leads up to granite breccia with $\mathrm{SiO}_{2}$ and $\mathrm{Al}_{2} \mathrm{O}_{3}$ compositions similar to world average monzonite.

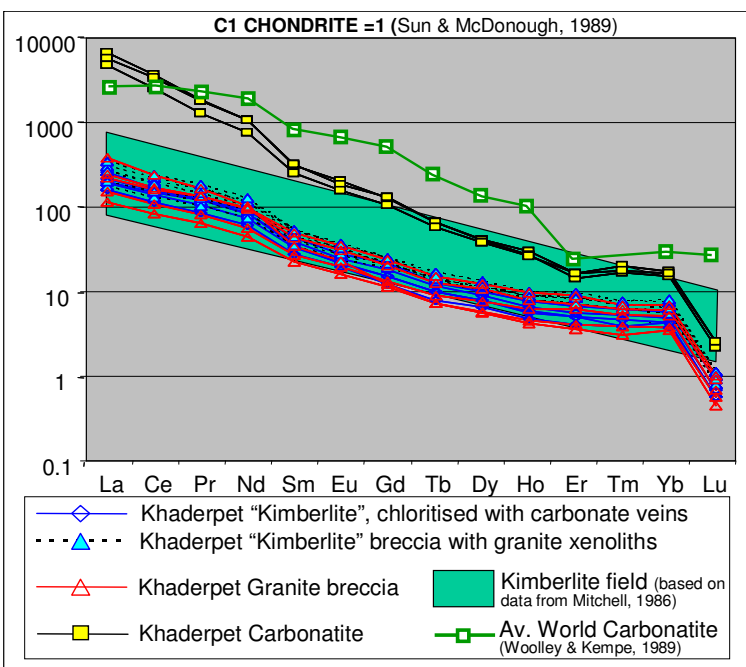

Figure 6-Rock / REE Chondrite for different facies of rocks from Khaderpet kimberlite - carbonatite pipe

The Rock/REE Chondrite plot for the Khaderpet ultramafic component (Fig. 6) shows affinities with kimberlite with strong enrichment in LREE. However, low $\mathrm{MgO}(\sim 13 \%)$ and high $\mathrm{CaO}(\sim 10 \%)$ values are more typical of ultramafic lamprophyres such as olivine melilitite. The Khaderpet carbonatite component on Fig. 6 shows extreme enrichment in REE approaching that of world-average carbonatite.

\section{Discussion and Conclusions}

Difficulties of assigning diamond-bearing ultramafics in the Dharwar Craton to precisely defined rock names has led to their being variously called kimberlite, lamproite, melilitite, kimberlitic lamproite, "extreme type", "intermediate variety", and "transitional", as discussed by Haggerty and Birkett (2004) who refer to them as Kimberlite Clan rocks. At Khaderpet, the extensive alteration of the ultramafic rock component hinders clear and precise classification of rock type. The juxtaposition at Khaderpet of diamondiferous, ultramafics, carbonatite and fenitised wall rock breccias raises the issue of kimberlite-carbonatite relationships and definitions. The extensive degree of fenitisation recalls the similar strong metasomatic aureole associated with the Murowa and Sese kimberlites in Zimbabwe (Smith et al., 2004). The petrographic and chemical affinities with either kimberlite or ultramafic lamprophyre have a possible counterpart in the Winter Coast field of pipes near Arkhangelsk, Russia where a similar association of diamondiferous kimberlites, barren melilite-bearing alkali picrites, olivine lamproites and carbonatites has been described (Mahotkin et al., 2000).
Taken in isolation, the calcium carbonate intrusive at Khaderpet would be considered a carbonatite. Given its association with Kimberlite Clan rocks it might be genetically a late-stage fractionation product of the Khaderpet diamond-bearing ultramafic magma. What is clear is that the Khaderpet ultramafic magma can evolve to produce a rock with all the chemical and petrological characteristics of a carbonatite with an associated widespread aureole of fenitisation.

\section{References}

Bhaskar Rao, Y.J., Naha, K., Srinivasan, R. and Gopalan, K. (1991) - Geology, geochemistry and geochronology of the Archean Peninsular Gneiss around Gorur, Karnataka, India, Journal of Earth Science, Vol. 100, no. 4, December, 1991

Chalapathi Rao, N.V. (2007) - Chelima dykes, Cuddapah Basin, Southern India: A review of the age, petrology, geochemistry and petrogenesis of world's oldest lamproites; Journal Geological Society India, Vol. 69, Mar 2007, pp 523-538

Gupta, S., Rai, S.S., Prakasam, K.S., Srinagesh, D., Chadha, R.K., Priestley, K. and Gaur, V.K. (2003) - First evidence for anomalous thick crust beneath midArchean western Dharwar craton, Current Science, vol. 84, No. 9, May 2003.

Haggerty, S.E., and Birkett, T., 2004. Geological setting and chemistry of kimberlite clan rocks in the Dharwar Craton, India. Lithos, Volume 76, Issues 1-4, pp. 535549.

Kumar, A.; Heaman, L. M., Manikyamba, C. (2007); Mesoproterozoic kimberlites in South India: A possible link to $\sim .1$. Ga global magmatism, Precambrian Research V 154 (2007) pp 192-2004

Kumar, A., Gopalan, K., Rao, K.R.P. and Nayak, S.S. (2001) - Rb-Sr age of kimberlites and lamproites from Eastern Dharwar Craton, South India; Journal. Geological Society India, Vol. 58, Aug 2001, pp 135 - 441

Mahotkin, I.L., Gibson, S.A., Thompson, R.N., Zhuravlev, D.Z., Zherdev, P.U., 2000. Late Devonian Diamondiferous Kimberlite and Alkaline Picrite (protokimberlite?) Magmatism in the Arkhangelsk Region, NW Russia. Journal of Petrology, 41, 2, 201-227.

Mitchell, R.H., 1986. Kimberlites. Mineralogy, Geochemistry and Petrology. Plenum Press, New York, 442 p.

Naha, K., Srinivasan, R. and Jayaram, S. (2005) - Structural evolution of the Peninsular Gneiss - an early Precambrian migmatite complex from South India, International Journal of Earth Sciences, Vol. 79, No. 1, February 1990.

Rock, N.M.S., 1991. Lamprophyres. Blackie and Son Ltd., Glasgow, 285 p.

Scott Smith, B.H, (2007) - Lamproites and Kimberlites of India, Journal of Geological Society of India, Vol. 69, pp. $450-461$.

Smith, C.B., Sims, K., Chimuka, L., Duffin, A., Beard, A.D., and Townend, R., 2004. Kimberlite metasomatism at Murowa and Sese pipes, Zimbabwe. Lithos, Volume 76, pp. 219-232

Sparks, R.S.J., Baker, L., Brown, R.J., Field, M. Schumacher, J., Stripp, G., and Walters, A., 2006. Dynamical constraints on kimberlite volcanism. Journal of Volcanology and Geothermal Research 155, 18-48.

Woolley, A.R., and Kempe, R.C., 1989. Carbonatites: nomenclature, average chemical compositions, and element distribution. In: Bell, K (ed.): Carbonatites: Genesis and Evolution. Unwin Hyman, London, pp. 114 